Techniques \& Culture

Revue semestrielle d'anthropologie des techniques

$20 \mid 1993$

Variables et constantes

\title{
Des lapons sans lasso
}

\section{Yves Delaporte}

\section{(2) OpenEdition}

Journals

Édition électronique

URL : https://journals.openedition.org/tc/644

DOI : $10.4000 /$ tc. 644

ISSN : 1952-420X

Éditeur

Éditions de l'EHESS

Édition imprimée

Date de publication : 1 novembre 1993

ISSN : 0248-6016

Référence électronique

Yves Delaporte, «Des lapons sans lasso », Techniques \& Culture [En ligne], 20 | 1993, mis en ligne le 05 janvier 2006, consulté le 29 septembre 2022. URL : http://journals.openedition.org/tc/644 ; DOI : https://doi.org/10.4000/tc.644

Ce document a été généré automatiquement le 29 septembre 2022

Tous droits réservés 


\section{Des lapons sans lasso}

Yves Delaporte 